\title{
Antiparasitic drugs: in vitro tests against nematophagous fungi
}

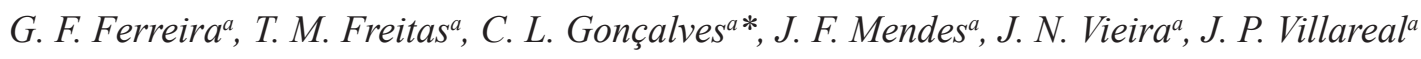 \\ and P. S. Nascente ${ }^{a}$ \\ ${ }^{a}$ Microbiology and Parasitology Department, Institute of Biology, Universidade Federal de Pelotas - UFPel, \\ Pelotas, RS, Brazil \\ *e-mail: carolina_lamg@yahoo.com.br
}

Received: March 28, 2015 - Accepted: August 2, 2015 - Distributed: November 30, 2016

\begin{abstract}
The use of biological agents has been intensified in recent years against eggs and larvae of gastrointestinal nematodes as an alternative control method in pasture plant health management, with the concomitant use with antiparasitic drugs still occurring. The aim of this study was to test the in vitro activity of the following antiparasitic drugs: Ivermectin and albendazole against the following nematophagous fungi: Paecilomyces fumosoroseus, Paecilomyces lilacinus and Paecilomyces variotii. The agar diffusion test was performed using an initial concentration of $0.0016 \mathrm{~g} / \mathrm{mL}$ of each drug, after solidification of the culture medium containing the drug concentration each nematophagous fungi was inoculated. The results showed that in a concentration of $80 \mu \mathrm{g} / \mathrm{mL}$, the fungal growth decreased, however, with the concentration of $160 \mu \mathrm{g} / \mathrm{mL}$, there was no fungal growth in both drugs, compared to the control, which indicates an inhibition in the development of the nematophagous fungi studied when they come in contact with ivermectin and albendazole.
\end{abstract}

Keywords: ivermectin, albendazole, biological control.

\section{Antiparasitários: teste in vitro contra fungos nematófagos}

\section{Resumo}

O uso de agentes biológicos que atuam em ovos e larvas de nematódeos gastrintestinais como uma alternativa para o manejo de pastagens de saúde tem se intensificado nos últimos anos, bem como o uso concomitante com outros medicamentos antiparasitários. O objetivo deste estudo foi testar o efeito in vitro dos fármacos Ivermectina e Albendazol em fungos nematófagos Paecilomyces fumosoroseus, Paecilomyces lilacinus e Paecilomyces variotii. Foi utilizada a técnica de difusão em agar, sendo preparado a partir de uma concentração inicial de $0,0016 \mathrm{~g} / \mathrm{mL}$ de cada uma das drogas e diluídas em meio de cultura, com posterior semeadura dos fungos nematófagos. Os resultados mostraram que na concentração de $80 \mu \mathrm{g} / \mathrm{mL}$, o crescimento diminuiu, no entanto, com a concentração de $160 \mu \mathrm{g} / \mathrm{mL}$ de ambas as drogas, não houve crescimento de fungos durante o período de estudo, em comparação com o controle, indicando a inibição do desenvolvimento dos fungos nematófagos estudados quando em contato com a Ivermectina e Albendazol.

Palavras-chave: ivermectina, albendazol, controle biológico.

\section{Introduction}

Gastrointestinal nematode infections are a limiting factor in the animal's production in raised field systems (Waghorn et al., 2003). Several control programs have been developed with the goal of minimizing the side effects of endoparasitoses on ruminant production. Among this programs, we can highlight the use of anthelmintic compounds with the aimed of reduction of infective larvae on pasture by decreasing the population of adult parasites in animals. However, despite the use of antiparasitic compounds as main tools, its use have negative effects, such as: drug residues in animal products (Padilha, 1996), toxic effects in the environment and in non-target organisms (Lumaret and Errouissi, 2002) and the develop of anthelmintic resistance (Kaplan, 2004; Fortes and Molento, 2013).
The use of biological agents against eggs and larvae of gastrointestinal nematodes as an alternative control method in pasture cleaning management has been intensified in recent years. The nematophagous fungi are the most studied microorganisms for this kind of purpose (Graminha et al., 2005; Soares et al., 2014). These fungi live in the soil organic matter, in which they developed a parasitic or predatory relation with nematodes, classified as: Ovicidal, endo-parasites and predators. The cosmopolitan nematophagous fungi are harmless to animals and humans; they can act as anthelmintic antagonist with the capacity of being used in the control of parasites eggs in the environment (Barron, 1977; Braga et al., 2009). Thus, several species of nematophagous fungi that infect the larval forms of parasites on pasture has been reported as 
a biological alternative method for nematodes affecting ruminants (Saumell and Fernández, 2000; Silva et al., 2013).

Due to several research works on biological control methods and the ignorance on the side effect of using concomitant anthelmintics together with biological control for anthelmintic treatment, this work aims to determine the in vitro effect of the following drugs commonly used: Ivermectin and Albendazole on the following nematophagous fungi: P. fumosoroseus, P.lilacinus and P. variotii.

\section{Material and Methods}

The nematophagous fungi used in this study were obtained from the CENARGEN (National Research Center for Genetic Resources and Biotechnology) - EMBRAPA (Federal District). The ivermectin and albendazole drugs were purchased from its manufacturer in the formulation of commercial use. The two cited antiparasitics were tested against the following nematophagous fungi: P. fumosoroseus, $P$. lilacinus and $P$. variotii.

The agar diffusion test was used for the drugs preparation according M2-A8 (CLSI, 2003) with an inoculum preparation with filamentous fungi based on the document M38-A2 (CLSI, 2008) adapted to nematophagous fungi and antiparasitic. Drugs were prepared with an initial concentration of 1.6mg. $\mathrm{mL}^{-1}$ (M38-A2, 2008). For each nematophagous fungi tested, we used three Petri plates containing Potato Dextrose Agar (PDA) and each plate with different antiparasitic concentration, one plate considered the positive control containing (PDA 20ml), another plate containing PDA $(19 \mathrm{~mL})+$ antiparasitic $(1 \mathrm{~mL})(0.08 \mathrm{mg}$. $\left.\mathrm{mL}^{-1}\right)$ and the last one containing PDA $(18 \mathrm{ml})+$ antiparasitic $(2 \mathrm{~mL})\left(0.16 \mathrm{mg} \cdot \mathrm{mL}^{-1}\right)$, after solidification each fungi was inoculated and the plates were incubated at $25^{\circ} \mathrm{C}$ for seven days. The test was performed by triplicate.

The results were evaluated in the $3 \mathrm{rd}$, 5 th and 7 th day after the inoculation of the fungi, by measuring the diameter of fungal growth on each plate and on each fungal comparing to the fungal growth in the positive control and thereby calculating the percentage reduction.

Statistical analyses: Data were analysed by One-way ANOVA on Ranks (Kruskal-Wallis) and Tukey Tests using SigmaStat software, Version 11.0 (Jandel Corporation, San Raphael, CA). Statistical difference was accepted when the $P$-value was $<0.05$.

\section{Results}

The results were based on the average measurements of three reading evaluation, on days 3,5 and 7 after inoculation, inhibitory variations between the tested drugs are shown in Table 1.

At the concentration of $0.08 \mathrm{mg} \cdot \mathrm{mL}^{-1}$ and when compared with the control group, ivermectin had an inhibitory effect of $38 \%$ when tested in P. variotii, of $62.7 \%$ in P. fumosoroseus and of $11.1 \%$ in P. lilacinus. Also when compared with the control group and at the same concentration albendazole had an inhibitory effect of $78.8 \%$ in P. variotii, of $64.6 \%$ in P. fumosoroseus and of $60.4 \%$ in P. lilacinus. However, the drugs at a concentration of $0.16 \mathrm{mg} \cdot \mathrm{mL}^{-1}$ showed inhibition of all fungal growth during the seven days of the study, compared to the control where the growth of the organism occurred.

\section{Discussion}

Combined use of chemical and biological control methods may be a viable strategy for livestock health, in reducing costs, in low resistance, in low toxicity and in a better management, in addition for reducing residues in animal origin products as well into the environment (Soares and Monteiro, 2011). However, there are no available studies reporting an evaluation of the alterations that can cause the use of combine antiparasitic drugs with this biological control method in different nematophagous fungus development variables.

Studies have shown that the use of chemicals in the agriculture practice may have an antagonistic, a synergistic, or no effect, on the insecticide or acaricide activity in the agro ecosystem entomopathogens (Oliveira et al., 2002).

Experiments have been conducted in the detection of a pesticide effect on entomopathogenic fungi (Anhalt et al., 2010; Oliveira and Neves, 2004; Alizadeh et al., 2007). Borges and Vila Nova (2011) reported the occurrence of physiological alterations which includes the loss of entomopathogenic fungus performance activity on arthropods after the use of chemicals.

The three fungi used in this study were completely inhibited with an ivermectin and albendazole concentration of $160 \mathrm{mg} / \mathrm{mL}$. However, when the albendazole drug was tested at a concentration of $80 \mathrm{mg} / \mathrm{mL}$ there was a considerable fungi growth reduction $(>60 \%)$ in the three tested fungi. In the other hand the ivermectin drug; only

Table 1. Diameter growth (average) and percentage reduction of nematophagous fungi in Potato Dextrose Agar plates containing Ivermectin and Albendazole antiparasitic compared to control.

\begin{tabular}{|c|c|c|c|c|c|c|}
\hline \multirow{2}{*}{$\begin{array}{c}\text { Nematophagous } \\
\text { Fungus }\end{array}$} & \multicolumn{3}{|c|}{ Ivermectin } & \multicolumn{3}{|c|}{ Albendazole } \\
\hline & Control & 0.08mg.mL $L^{-1}$ & $0.16 \mathrm{mg} \cdot \mathrm{mL}^{-1}$ & Control & $0.08 \mathrm{mg} \cdot \mathrm{mL}^{-1}$ & $0.16 \mathrm{mg} . \mathrm{mL}^{-1}$ \\
\hline P. variotii & $8 \mathrm{~cm}$ & $4.96 \mathrm{~cm}(38 \%)$ & $\mathrm{NG}$ & $5 \mathrm{~cm}$ & $1.06 \mathrm{~cm}(78.8 \%)$ & $\mathrm{NG}$ \\
\hline P.fumosoroseus & $7 \mathrm{~cm}$ & $2.63 \mathrm{~cm}(62.7 \%)$ & NG & $8 \mathrm{~cm}$ & $2.83 \mathrm{~cm}(64.6 \%)$ & NG \\
\hline P.lilacinus & $4.16 \mathrm{~cm}$ & $3.7 \mathrm{~cm}(11.1 \%)$ & NG & $4.8 \mathrm{~cm}$ & $1.9 \mathrm{~cm}(60.4 \%)$ & $\mathrm{NG}$ \\
\hline
\end{tabular}

NG - no growth. Identical lowercase letters a-c denote no significant difference, and different letters denote a statistically significant difference $(\mathrm{P}<0.05 ; \mathrm{n}=3)$. 
showed reduction in P. fumosoroseus for more than $60 \%$. The inhibition action of these drugs over the nematophagous fungi can occur in the soil since they are eliminated by the animal body and the animal waste, because these fungi are administered orally. In vivo studies are needed to confirm this action.

According to Hirose et al. (2001), the use of chemicals is incompatible with fungi, inhibiting their development and reproduction, therefore affecting an effective biological control. This incompatibility has been well-characterized by studies demonstrating that associations organophosphates are not recommended for tick control in the field, since all treatments performed containing these active components had a toxic effect on Beauveria bassania. These observations concord with those reported by Oliveira and Neves (2004) who, upon analyzing the compatibility of acaricides with B. bassania used on farmland, found that formulations that belong to the organophosphorus and organotin chemical groups drastically affected the conidium germination, as well as the vegetative growth and sporulation in isolates belonging to this entomopathogen. Conversely, the most compatible formulations with the fungus were those belonging to the avermectin and pyrethroid chemical groups.

Studies made by Asi et al. (2010) evaluate the influence of some insecticides on mycelial growth, and conidial (spore) germination of Metarhizium anisopliae and $P$. fumosoroseus showing that all insecticides inhibited fungus mycelial growth and conidial germination in a significantly way. A similar inhibitory effect with the use of antiparasitics in this study was observed for P. fumosoroseus, in which the chemicals levamisole and closantel showed the most significant inhibitory effect. Also was noted a high susceptibility of the isolated fungal $D$. flagrans to all drugs tested in vitro, respectively a differentiation from the other fungal isolates evaluated is worthy to mention.

\section{Conclusion}

The tested drugs showed inhibitory effect concentrationsdependent against the tested fungi used for biological control in this study: Paecilomyces fumosoroseus, Paecilomyces lilacinus and Paecilomyces variotii, being albendazole the drug that had highest inhibitory activity over these three microorganisms when compared with ivermectin. It is important to mention that the experiments in this study were conducted in vitro, and that the results obtained may not be repeated in studies in vivo. For this purpose, research aiming to evaluate drug toxicity under such conditions is needed.

\section{References}

ALIZADEH, A., SAMIH, M.A., KHEZRI, M. and RISEH, R.S., 2007. Compatibility of Beauveria bassiana (Bals.) Vuill. with several pesticides. International Journal of Agriculture and Biology, vol. 9, pp. 31-34.

ANHALT, F.A., AZEVEDO, J.L., SUGAYAMA, R.L., SPECHT, A. and BARROS, N.M., 2010. Potential of Metarhizium anisopliae
(Metsch.) Sorokin (Ascomycetes, hypocreales) in the control of Bonagota salubricola (Meyrick) (Lepidoptera, Tortricidae) and its compatibility with chemical insecticides. Brazilian Journal of Biology $=$ Revista Brasileira de Biologia, vol. 70, no. 4, pp. 931-936. PMid:21180896.

ASI, M.R., BASHIR, M.H., AFZAL, M., ASHFAQ, M. and SAHI, S.T., 2010. Compatibility of entomopathogenic fungi, Metarhizium anisopliae and Paecilomyces fumosoroseus with selective insecticides. Pakistan Journal of Botany, vol. 42, pp. 4207-4214

BARRON, G.L., 1977. The nematode-destroying fungi. Ontario: Canadian Biological Publications. $140 \mathrm{p}$.

BORGES, L.R. and VILA NOVA, M.X., 2011. Associação de inseticidas químicos e fungos entomopatogênicos no Manejo Integrado de Pragas: uma revisão. Ambiência, vol. 7, no. 1, pp. 179-190.

BRAGA, F.R., SILVA, A.R., ARAUJO, J.M., FERREIRA, S.R., ARAÚJO, J.V. and FRASSY, L.N., 2009. Ação ovicida do fungo Pochonia chlamydosporia sobre ovos de Enterobius vermicularis. Revista do Instituto Adolfo Lutz, vol. 68, pp. 318-321.

CLINICAL AND LABORATORY STANDARDS INSTITUTE - CLSI, 2003. Padronização dos testes de sensibilidade a antimicrobianos por disco-difusão: norma aprovada: M2-A8, vol. $23, n .1 .8$ th ed. Wayne: CLSI.

\section{CLINICAL AND LABORATORY STANDARDS INSTITUTE} - CLSI, 2008. Reference method for broth dilution antifungal susceptibility testing of filamentous fungi: approved standard document: M38-A2. Wayne: CLSI.

FORTES, F.S. and MOLENTO, M.B., 2013. Resistência antihelmíntica em nematoides gastrintestinais de pequenos ruminantes: avanços e limitações para seu diagnóstico. Pesquisa Veterinaria Brasileira, vol. 33, no. 12, pp. 1391-1402. http://dx.doi.org/10.1590/ S0100-736X2013001200001.

GRAMINHA, É.B.N., MONTEIRO, A.C., SILVA, H.C., OLIVEIRA, G.P. and COSTA, A.J., 2005. Controle de nematóides parasitos gastrintestinais por Arthrobotrys musiformis em ovinos naturalmente infestados mantidos em pastagens. Pesquisa Agropecuaria Brasileira, vol. 40, no. 9, pp. 927-933. http://dx.doi. org/10.1590/S0100-204X2005000900013.

HIROSE, E., NEVES, P.M.O.J., ZEQUI, J.A.C., MARTINS, L.H., PERALTA, C.H. and MOINO, J.R.A., 2001. Effect of biofertilizers and neem oil on the entomopathogenic fungi Beauveria bassiana (Bals.) Vuill. and Metarhizium anisopliae (Metsch.). Brazilian Archives of Biology and Technology, vol. 44, pp. 419-423.

KAPLAN, R.M., 2004. Drug resistance in nematodes of veterinary importance: a status report. Trends in Parasitology, vol. 20, no. 10, pp. 477-481. http://dx.doi.org/10.1016/j.pt.2004.08.001. PMid:15363441.

LUMARET, J.P. and ERROUISSI, F., 2002. Use of anthelmintics in herbivores and evaluation of risks for the non target fauna of pastures. Veterinary Research, vol. 33, no. 5, pp. 547-562. http:// dx.doi.org/10.1051/vetres:2002038. PMid:12387489.

OLIVEIRA, R.C. and NEVES, P.M.O.J., 2004. Compatibility of Beauveria bassiana with acaricides. Neotropical Entomology, 
vol. 33, no. 3, pp. 353-358. http://dx.doi.org/10.1590/S1519$566 \times 2004000300013$

OLIVEIRA, R.C., NEVES, P.M.O.J., GUZZO, E.C. and ALVES, V.S., 2002. Compatibilidade de fungos entomopatogênicos com agroquímicos. Semina: Ciências Agrárias, vol. 23, pp. 211-216.

PADILHA, T., 1996. Resíduos de anti-helmínticos na carne e leite. In: T. PADILHA, ed. Controle dos nematódeos gastrintestinais em ruminantes. Coronel Pacheco: EMBRAPA/CNPGL. pp. 77-93.

SAUMELL, C.A. and FERNÁNDEZ, A.S., 2000. Hongos nematófagos para el control biológico de nemátodos parásitos de rumiantes. RevMed Vet., vol. 81, pp. 270-273.

SILVA, M.E., ARAÚJO, J.V., BRAGA, F.R., FREITAS SOARES, F.E. and RODRIGUES, D.S., 2013. Control of infective larvae of gastrointestinal nematodes in heifers using different isolates of nematophagous fungi. Revista Brasileira de Parasitologia
Veterinária, vol. 22, no. 1, pp. 78-83. http://dx.doi.org/10.1590/ S1984-29612013005000012. PMid:23538499.

SOARES, F.B. and MONTEIRO, A.C., 2011. Compatibilidade de Metarhizium anisopliae com carrapaticidas químicos. Arquivos do Instituto Biologico, vol. 78, pp. 385-391.

SOARES, F.E.F., QUEIROZ, J.H., BRAGA, F.R., LIMA, W.S., ZAMPROGNO, T.T. and ARAÚJO, J.V., 2014. Proteolytic activity of the nematophagous fungus Arthrobotrys sinensis on Angiostrongylus vasorum larvae. BMC Research Notes, vol. 7, no. 1, pp. 811-816. http://dx.doi.org/10.1186/1756-0500-7-811. PMid:25406419.

WAGHORN, T.S., LEATHWICK, D.M., CHEN, L.Y. and SKIPP, R.A., 2003. Efficacy of de nematode-trapping fungus Duddingtonia flagransagainst three species of gastrointestinal nematodes in laboratory faecal cultures from sheep and goats. Veterinary Parasitology, vol. 118, no. 3-4, pp. 227-234. http:// dx.doi.org/10.1016/j.vetpar.2003.09.018. PMid:14729170. 